\title{
Complete Resolution of Erythrodermic Psoriasis in an HIV and HCV Patient Unresponsive to Antipsoriatic Treatments after Highly Active Antiretroviral Therapy (Ritonavir, Atazanavir, Emtricitabine, Tenofovir)
}

\author{
Andrea Chiricozzi ${ }^{a}$ b Rosita Saraceno ${ }^{a}$ Maria Vittoria Cannizzaro ${ }^{a}$ Steven P. Nisticò ${ }^{a}$ \\ Sergio Chimenti ${ }^{a} \quad$ Alessandro Giunta $^{a}$

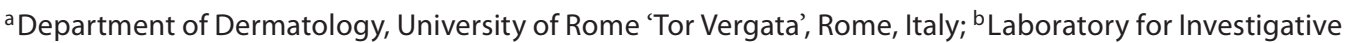 \\ Dermatology, Rockefeller University, New York, N.Y., USA
}

\section{Key Words}

Human immunodeficiency virus $\cdot$ Hepatitis $\mathrm{C}$ virus - Psoriasis - Anti-tumor necrosis factor- $\alpha$ agent $\cdot$ Highly active antiretroviral therapy

\begin{abstract}
Background: Psoriasis is a chronic, inflammatory disease affecting 2-3\% of the worldwide population, and it may worsen with HIV or be detected as HIV cutaneous manifestation. HIV-related psoriasis shows a severe and prolonged clinical course with more frequent exacerbations. The management of this condition is challenging because immunomodulating and immunosuppressant agents may have variable and partial efficacy, and therefore, antiretroviral treatment represents a potential adjunctive therapeutic option. Results: In the case we report, the HIV test was shown to be crucial for driving the therapeutic approach. Indeed, antiretroviral agents have been proven to be effective in the treatment of HIV+ psoriasis as first-line therapy. Conclusion: The HIV test should be considered in high-risk patients affected by severe psoriasis and resistant to conventional and biological treatments.
\end{abstract}

Copyright ๑ 2012 S. Karger AG, Basel

\section{Introduction}

Psoriasis is a chronic, inflammatory disease affecting $2-3 \%$ of the worldwide population [1]. The most common clinical phenotype, namely plaque-type psoriasis, is characterized by symmetrical, erythematosus, scaly plaques localized on the extensor surfaces of the skin, scalp, and lower back, although any site can be affected. Psoriasis may represent a cutaneous manifestation of human immunodeficiency virus (HIV) infection, and can potentially provide clinical evidence regarding the progression of the infection [2].

Hence, a worsening of psoriasis in high-risk patients (e.g. story of drug abuse, hepatitis $\mathrm{C}$ virus, $\mathrm{HCV}$, infection) or in patients with a multidrug resistance might be determined by a latent infection which laboratory tests can easily detect, with the exception of the HIV test which legally needs a written consent signed by patients who, in some cases, could be reluctant to perform it. Though HIV testing is not mandatory in the screening for biological therapies, it could prove very useful in the selection of the optimal therapeutic option for the treatment of a challenging condition such as HIV-related psoriasis.
We present the case of severe psoriasis associated with an undiagnosed HIV infection that was found to be resistant to multiple antipsoriatic therapies. Diagnosis and treatment of HIV led to an improvement of the skin condition.

Moreover, we reviewed the literature, focusing our attention on the wide therapeutic armamentarium available in the treatment of HIV-related psoriasis.

\section{Case Report}

A 50-year-old Caucasian man, affected by moderate-to-severe plaque-type psoriasis since the age of 40 years, was referred to our Department with a severe erythrodermic flare. The patient's clinical notes mentioned a chronic, asymptomatic HCV infection since the age of 30 . The patient was unresponsive to conventional systemic antipsoriatic treatments (cyclosporine $3 \mathrm{mg} / \mathrm{kg}$ daily and acitretin $25 \mathrm{mg}$ daily) and systemic steroids (methylprednisolone $0.5 \mathrm{mg} / \mathrm{kg}$ daily), claiming that erythrodermic flares characterized all episodes of psoriasis exacerbations. Screening for biologicals, according to European Guidelines [1], was performed. Serum transami-

\section{KARGER}

E-Mail karger@karger.com

www.karger.com/drm (c) 2012 S. Karger AG, Basel

$1018-8665 / 12 / 2254-0333 \$ 38.00 / 0$
Andrea Chiricozzi, MD

Department of Dermatology, University of Rome 'Tor Vergata' Viale Oxford, 81 IT-00133 Rome (Italy)

E-Mail chiricozziandrea@gmail.com 
nases were within normal ranges, the $\mathrm{HCV}$ replication rate was low, and ultrasound demonstrated that liver dimension and parenchyma structure were conserved. According to blood and imaging results, the patient was considered eligible for biologicals. Of note, the patient refused to sign the informed consent for an HIV test recommended (but not mandatory) [1] prior to a biological therapy. Then infliximab, a chimeric anti-tumor necrosis factor (TNF)- $\alpha$ monoclonal antibody, $5 \mathrm{mg} /$ $\mathrm{kg}$ intravenously, was initiated. A significant improvement was observed as soon as week 2, but a loss of efficacy leading to drug discontinuation was observed at week 30 and, after a 3-month washout period, the patient was switched to adalimumab, a human anti-TNF- $\alpha$ monoclonal antibody, $40 \mathrm{mg}$ every other week. Similarly to infliximab, adalimumab initially controlled psoriasis but was discontinued because of inefficacy after 18 months of continuous treatment. Adverse events were not referred during infliximab or adalimumab treatment; in contrast, erythrodermic flares and loss of efficacy to both anti-TNF- $\alpha$ agents were observed. A screening evaluation for biological eligibility was again performed and, remarkably, again the patient refused signing the HIV test consent form. Etanercept $50 \mathrm{mg}$ twice weekly was subcutaneously administered and suddenly, after the third injection, the patient was referred to our outpatient clinic with erythroderma (PASI 48), fever $\left(39.2^{\circ} \mathrm{C}\right)$, and a nonproductive cough. The patient's clinical conditions were severe, deserving hospitalization. Blood tests, including urine culture and hemoculture for mycetes, aerobic and anaerobic bacteria, were performed. Cell blood count showed increased neutrophils with a reduction of $\mathrm{CD} 3+/ \mathrm{CD} 45+\mathrm{T}$ lymphocytes (520 cells/ml; normal range: 690-2,540 cells $/ \mathrm{ml})$. Several pathogens, including $\mathrm{HCV}$, hepatitis B and A virus, tuberculosis, Treponema pallidum, Toxoplasma, herpes simplex virus $1-2$, varicella-zoster virus, cytomegalovirus and Epstein-Barr virus were ruled out, and at last, the patient signed the informed consent for an HIV test. Hydration, broad-spectrum antibiotic therapy, paracetamol and methylprednisolone were administered. In order to rule out an endocarditis or an atypical pulmonary infection, an echocardiogram and a chest high-resolution computerized tomography were performed. The echocardiogram fell within normal ranges (sinus rhythm at a frequency of 75 beats/min, normal atrial-ventricular and intraventricular conduction; electrical axis on the left; normal phase of ventricular repolarization). The high-resolution computerized tomography showed an unspecific inflammatory image at bilateral medium lobes, and a bronchoscope evaluation with bronchoalveolar lavage-derived liquid examination bore no specific results (alveolar macrophages and neutrophils). During imaging procedures, the HIV test was positive $(780,000$ copies $/ \mathrm{ml})$ whereby a highly active antiretroviral therapy (HAART; ritonavir, atazanavir, emtricitabine, tenofovir) was administered. Unpredictably, though all antipsoriatic treatments were interrupted, psoriasis improved dramatically with a complete resolution of the erythroderma (PASI 0) only 2 weeks after the introduction of HAART (fig. 1). Such improvement of skin symptoms correlates with the rapid depletion of viral copies and the impressive increase in total lymphocytes $(791$ cells $/ \mathrm{ml}$ and 2,235 cells $/ \mathrm{ml}$ at baseline and at week 2 , respectively) and CD3+/CD45+ T cell count (520 cells/ml and 1,739 cells $/ \mathrm{ml}$ at baseline and week 2 , respectively). After 24 weeks, total lymphocytes and CD3+/CD45+ T cell count were within normal ranges and the patient showed a complete remission of psoriasis. HCV viral load as well as liver functionality and structure were strictly monitored during the period of observation. We did not find any progression of the HCV infection, and according to the infectious disease consultations, we did not administer any specific anti-HCV treatment.

\section{Review of the Literature}

It is uncertain whether the prevalence of psoriasis and psoriatic arthritis in HIVinfected subjects may be different with respect to the general population, but the clinical behavior of psoriasis seems to be altered among immunosuppressed patients. In particular, clinical observations demonstrate that HIV-affected psoriatic patients have a severe and prolonged clinical course with more frequent exacerbations, and that the development of skin lesions or arthritis symptoms in untreated HIV patients is associated with a poor prognosis and a mean survival expectancy ranging from 4 to 24 months after psoriasis onset [3-5]. These observations are of interest because $\mathrm{T}$ lymphocytes are cru- cially involved in both diseases but, while psoriasis results from T-cell activation, HIV infection switching to overt AIDS determines a massive T-cell depletion. Psoriasis in HIV patients usually develops in severe AIDS stages (CD4+ cell count less than 100 cells/ $\mu \mathrm{l}$ ) [6]. In contrast, in immunocompetent psoriatic patients, the treatment with an anti-CD1la antibody, which leads to a marked T-cell reduction, was demonstrated to be significantly effective in improving skin lesions [7]. The occurrence of psoriasis in AIDS patients may be correlated with an increase in CD8+ $\mathrm{T}$ cells in the peripheral blood, reflecting the psoriasis relapses in immunocompetent patients due to a significant infiltration of $\mathrm{CD} 8+\mathrm{T}$ cells both in the epidermis and dermis of lesional skin. Notably, in patients with CD4+ cell counts of less than 200 cells/ $\mu$ l, memory CD8+ $\mathrm{T}$ cells producing IL-17 and IFN- $\gamma$ comprise over $80 \%$ of the $\mathrm{T}$ cells in peripheral blood [2].

In 2009, the estimated number (expressed as percent of the total population in that age group) of HIV-infected young adults (15-49 years), whether or not they have developed AIDS, was 0.3 and 0.6 in Italy and in the USA, respectively (Global Health Observatory Data Repository, http://apps.who.int/ghodata). Consequently, an undiagnosed HIV infection must be carefully ruled out when an immunosuppressant is administered. However, when an HIV infection is diagnosed, the treatment of psoriasis is challenging. Despite the number of agents that have been proposed for this subset of patients, several reports exhibit controversial clinical outcomes. Although topical agents prevail as therapy of choice in HIV-infected patients, they prove somewhat ineffective in the treatment of widespread plaquetype psoriasis or in severe clinical variants, including pustular psoriasis and erythroderma. In these forms, the Medical Board of the National Psoriasis Foundation recommends UVB or psoralen plus UVA (PUVA) phototherapy $[8,9]$, though the increased risk for skin cancer, increase in HIV viral load and reduced resistance to infections should be carefully taken into consideration [2].

Acitretin, $75 \mathrm{mg} /$ day, has been reported as effective in one report [10], and an additional benefit was reached when ultraviolet light was combined in a RePUVA regimen [11]. Accordingly, systemic retinoids may be considered as first-line 


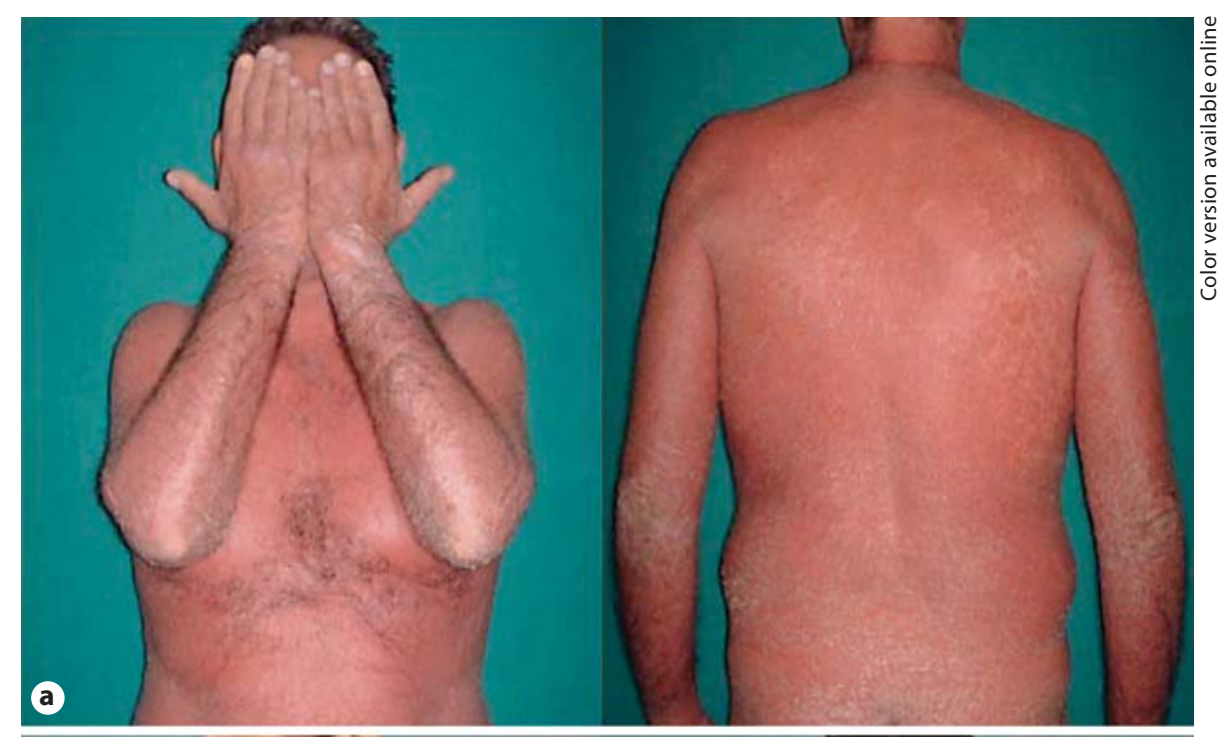

Fig. 1. a Erythrodermic flare (PASI 48) occurred before HAART. $\mathbf{b}$ Resolution of the erythrodermic flare (PASI 0) after 2 weeks of HAART. c Reduction of the HIV viral load was rapidly observed after the introduction of HAART. d Increased total lymphocyte count and CD3+/CD45+ T-cell count induced by HAART.

agents, although their use must be limited because of their contraindication (e.g. hepatic insufficiency or infections and alcohol intake), particularly in HIV high-risk cohorts (e.g. drug addicts). Concerning other systemic agents, methotrexate can be associated with severe leukopenia and
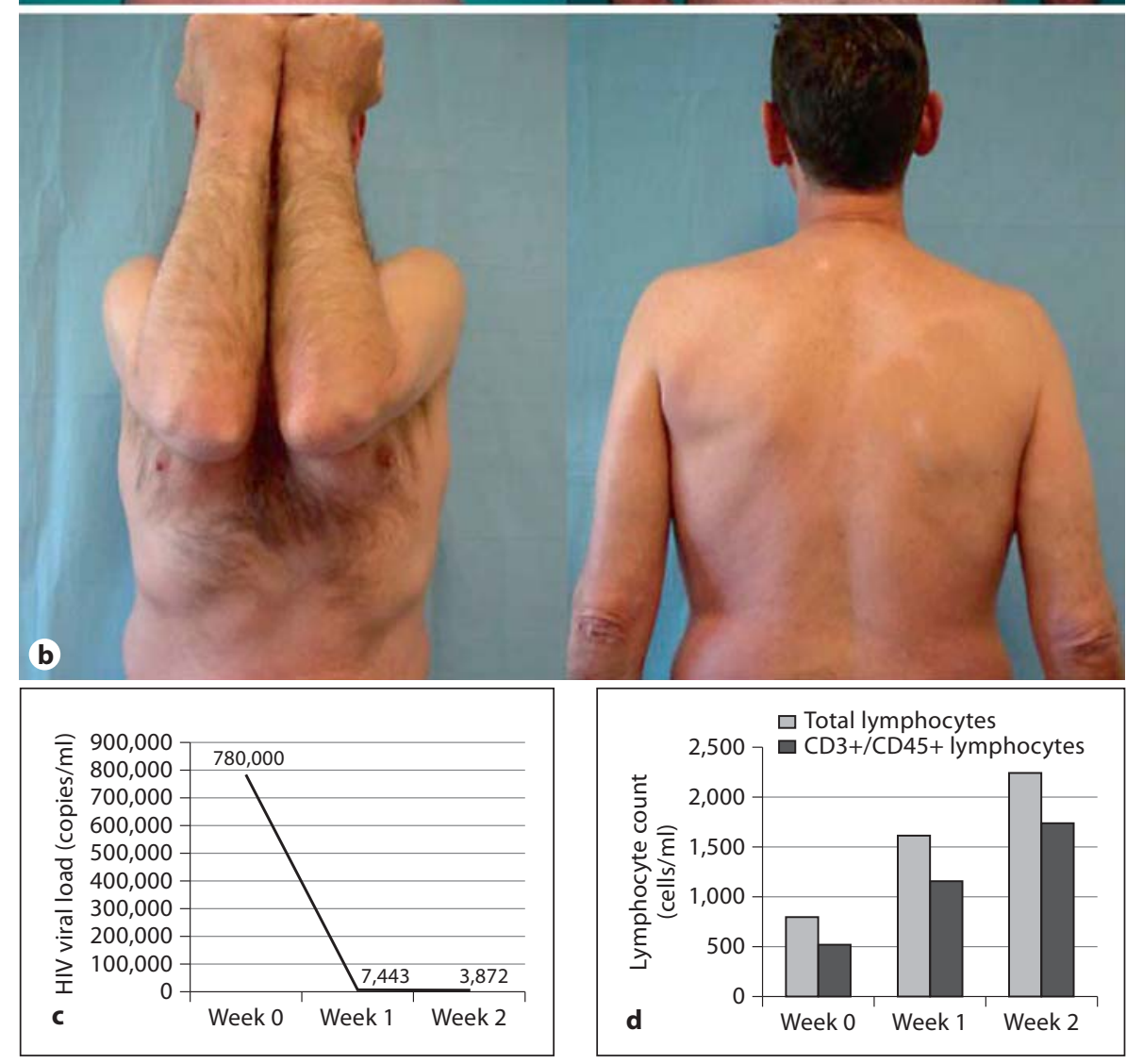

death in HIV-infected psoriatic patients and, thus, should be used with great caution $[12,13]$. Also, the use of cyclosporine and its benefits are controversial although cyclosporine may be potentially beneficial [14]. Indeed, in some reported cases, this agent was effective and safe in treating
HIV-correlated psoriasis, whereas in other cases, as in our report, it was found to be ineffective and unsafe [15-18]. The use of other antipsoriatic agents in HIV patients, including mycophenolate mofetil or hydroxyurea, is anecdotic [19]. Since TNF- $\alpha$ stimulates HIV transcription in vitro and 
could be involved in the pathogenesis of fatigue, fever and cachexia, theoretically, TNF- $\alpha$-blocking agents should be effective [20]. Furthermore, TNF- $\alpha$ is a pivotal mediator in granulomatous inflammation, generating concern about the use of anti-TNF- $\alpha$ in HIV patients, who often suffer from other comorbidities, including tuberculosis, hepatitis B and other opportunistic infections. In fact, etanercept, a soluble TNF- $\alpha$ receptor, has been effectively used, at a dosage of 25 or $50 \mathrm{mg}$, in patients with HIV-associated psoriasis or psoriatic arthritis [21, 22], though one of the treated patients withdrew due to frequent bacterial infections, not definitely related to the biological [20]. It is of note, in all patients, that the CD4+ cell count remains stable, and in one of them viral load was undetectable after 20 weeks [22]. Infliximab, a monoclonal anti-TNF- $\alpha$ antibody, was also demonstrated as effective and safe in HIV patients, rapidly improving both joint symptoms and skin lesions, and maintaining the therapeutic effect throughout a long-term follow up [23]. These observations have been bolstered by another report on a patient effectively treated with a low dose $(3 \mathrm{mg} / \mathrm{kg}$ instead of $5 \mathrm{mg} / \mathrm{kg}$ ) of infliximab [24]. These data are promising although further and larger trials are needed to validate these reports. Concerning nonantipsoriatic treatments, antiretroviral therapies have been demonstrated effective in treating psoriasis in single reported cases [25-29]. They include protease inhibitors (lamivudine, sa- quinavir, ritonavir) used as monotherapy or combined to nonnucleoside reverse transcriptase inhibitors (zidovudine, nevirapine, stavudine, tenofovir), or in addition to an entry inhibitor (enfuvirtide) [30, 31]. To our knowledge, only one open-label clinical trial on 19 evaluable patients treated with zidovudine has been performed. It showed marked efficacy in treating psoriasis with an improvement of skin manifestations in $90 \%$ of cases [32]. The usual HAART regimen contemplates different combinations of nucleoside reverse transcriptase inhibitors, protease inhibitors, and nonnucleoside reverse transcriptase inhibitors, and it has proven beneficial in $\mathrm{HIV}$-associated psoriasis [33]. Of note, zidovudine is rarely used in modern HAART regimens because of adverse effects, including dyslipidemia and lipoatrophy [2].

Though the resolution of psoriasis following HAART was often observed to be concomitant with the decrease in HIV viral load, another case conversely demonstrated a severe exacerbation of psoriasis during the treatment, resulting in raised CD4 and CD8 cell counts [34]. In our patient, HAART dramatically resolved skin lesions (PASI 48 and PASI 0 at baseline and at week 2 , respectively) and concomitantly normalized the total T-cell count (791 and 2,235 cells $/ \mathrm{ml}$ at baseline and at week 2 , respectively) and CD3+/CD45+ T-cell count (520 and 1,739 cells/ml at baseline and week 2 , respectively), demonstrating a more rapid efficacy than previous reported therapies. No exacerbation of psoriasis has been observed after the immune system restoration and no side effects were observed or reported by the patient during the treatment.

\section{Conclusion}

We described a psoriatic patient who was refractory or contraindicated to almost all known agents because of a latent, undiagnosed HIV infection, which might directly trigger psoriasis as a costimulatory factor through either antigenic presentation or as a source of superantigens [8]. Generally, a latent infection could be easily excluded by laboratory tests but the legal need of a specific, written consent to perform an HIV test poses an obstacle, with the majority of patients reluctant to perform it. This resistance to testing is likely attributed to a wrong social and cultural heritage and to the implications of a possible positivity. The HIV test is not routinely performed and is not mandatory as a screening test for biological therapies. However, the physician should strongly recommend the HIV test to high-risk patient cohorts or in patients with a multidrug resistance because HAART could represent an adjunctive therapeutic option.

\section{Disclosure Statement}

The authors state no conflict of interests.

\section{References}

1 Pathirana D, Ormerod AD, Saiag P, Smith C, Spuls PI, Nast A, Barker J, Bos JD, Burmester GR, Chimenti S, Dubertret L, Eberlein B, Erdmann R, Ferguson J, Girolomoni G, Gisondi P, Giunta A, Griffiths C, Hönigsmann H, Hussain M, Jobling R, Karvonen SL, Kemeny L, Kopp I, Leonardi C, Maccarone M, Menter A, Mrowietz U, Naldi L, Nijsten T, Ortonne JP, Orzechowski HD, Rantanen T, Reich K, Reytan N, Richards H, Thio HB, van de Kerkhof P, Rzany B: European S3-guidelines on the systemic treatment of psoriasis vulgaris. J Eur Acad Dermatol Venereol 2009;23:1-70.

-2 Morar N, Willis-Owen SA, Maurer T, Bunker CB: HIV-associated psoriasis: pathogenesis, clinical features, and management. Lancet Infect Dis 2010;10:470-478.
3 Duvic M, Johnson TM, Rapini RP, Freese T, Brewton G, Rios A: Acquired immunodeficiency syndrome-associated psoriasis and reactive arthritis. Arch Dermatol 1987;123: 1622-1632.

4 Colebunders R, Blot K, Mertens V, Dockx P: Psoriasis regression in terminal AIDS. Lancet 1992;339:1110.

5 Reveille JD, Conant MA, Duvic M: Human immunodeficiency virus-associated psoriasis, psoriatic arthritis, and reactive arthritis: a disease continuum? Arthritis Rheum 1990; 33:1574-1578.

6 Montazeri A, Kanitakis J, Bazex J: Psoriasis and HIV infection. Int J Dermatol 1996;35: 475-479.

7 Talamonti M, Spallone G, Di Stefani A, Costanzo A, Chimenti S: Efalizumab. Expert Opin Drug Saf 2011;10:239-251.
Menon K, Van Voorhees AS, Bebo BF Jr, Gladman DD, Hsu S, Kalb RE, Lebwohl MG, Strober BE; National Psoriasis Foundation: Psoriasis in patients with HIV infection: from the Medical Board of the National Psoriasis Foundation. J Am Acad Dermatol 2010;62:291-299.

-9 Patel RV, Weinberg JM: Psoriasis in the patient with human immunodeficiency virus. 2 . Review of treatment. Cutis 2008;82:202210.

10 Buccheri L, Katchen BR, Karter AJ, Cohen SR: Acitretin therapy is effective for psoriasis associated with human immunodeficiency virus infection. Arch Dermatol 1997;133: 711-715.

11 Mallon E, Bunker CB: HIV-associated psoriasis. AIDS Patient Care STDS 2000;14: 239-246. 
12 Masson C, Chennebault JM, Leclech C: Is HIV infection contraindication to the use of methotrexate in psoriatic arthritis? J Rheumatol 1995;22:2191.

13 Maurer TA, Zackheim HS, Tuffanelli L, Berger TG: The use of methotrexate for treatment of psoriasis in patients with HIV infection. J Am Acad Dermatol 1994;31:372-375.

14 Tourne L, Durez P, Van Vooren JP, Farber CM, Liesnard C, Heenen M, Parent D: Alleviation of $\mathrm{HIV}$-associated psoriasis and psoriatic arthritis with cyclosporine. J Am Acad Dermatol 1997;37:501-502.

15 Jacobson SK, Calne RY, Wreghitt TG: Outcome of HIV infection in transplant patient on cyclosporin. Lancet 1991;337:794.

16 Allen BR: Use of cyclosporine for psoriasis in HIV positive patient. Lancet 1992;339:686.

17 Linardaki G, Katsarou O, Ioannidou P, Karafoulidou A, Boki K: Effective etanercept treatment for psoriatic arthritis complicating concomitant human immunodeficiency virus and hepatitis $C$ virus infection. J Rheumatol 2007;34:1353-1355.

18 Calabrese LH, Lederman MM, Spritzler J, Coombs RW, Fox L, Schock B, Yen-Lieberman B, Johnson R, Mildvan D, Parekh N, AIDS Clinical Trials Group 334 Investigators: Placebo-controlled trial of cyclosporinA in HIV-1 disease: implications for solid organ transplantation J Acquir Immune Defic Syndr 2002;29:356-362.

19 Forman SB, Higginson R, Garrett AB: Psoriasis and psoriatic arthritis in a patient with HIV: response to mycophenolate mofetil treatment. J Drugs Dermatol 2008;7:972973.
20 Butera ST, Roberts BD, Folks TM: Ligand passing by the 75 tumour necrosis factor receptor enhances HIV-1 activation. Cytokine 1996;8:745-750.

21 Linardaki G, Katsarou O, Ioannidou P, Karafoulidou A, Boki K: Effective etanercept treatment for psoriatic arthritis complicating concomitant human immunodeficiency virus and hepatitis $C$ virus infection. J Rheumatol 2007;34:1353-1355.

22 Mikhail M, Weinberg JM, Smith BL: Successful treatment with etanercept of von Zumbusch pustular psoriasis in a patient with human immunodeficiency virus. Arch Dermatol 2008;144:453-456.

23 Sellam J, Bouvard B, Masson C, Rousière M, Villoutreix C, Lacombe K, Khanine V, Chennebault JM, Leclech C, Audran M, Berenbaum F: Use of infliximab to treat psoriatic arthritis in HIV-positive patients. Joint Bone Spine 2007;74:197-200.

24 Gill H, Majithia V: Successful use of infliximab in the treatment of reactive arthritis: a case report and discussion. Clin Rheumatol 2008;27:121-123.

25 Duvic M, Rios A, Brewton GW: Remission of AIDS associated psoriasis with zidovudine. Lancet 1987;ii:627.

26 Ruzicka T, Fröschl M, Hohenleutner U, Holzmann H, Braun-Falco O: Treatment of HIV-induced retinoid-resistant psoriasis with zidovudine. Lancet 1987;ii:1469-1470.

27 Feeney GF, Frazer I: AIDS-associated psoriasis responds to azidothymidine. Med J Aust 1988;148:155.
28 Kaplan MH, Sadick NS, Wieder J, Farber BF, Neidt GW: Antipsoriatic effects of zidovudine in human immunodeficiency virusassociated psoriasis. J Am Acad Dermatol 1989;20:76-82.

29 Díez F, del Hoyo M, Serrano S: Zidovudine treatment of psoriasis associated with acquired immunodeficiency syndrome. J Am Acad Dermatol 1990;22:146-147.

30 Fischer T, Schworer H, Vente C, Reich K, Ramadori G: Clinical improvement of HIVassociated psoriasis parallels a reduction of HIV viral load induced by effective antiretroviral therapy. AIDS 1999;13:628-629.

- 31 Vittorio Luigi De Socio G, Simonetti S, Stagni G: Clinical improvement of psoriasis in an AIDS patient effectively treated with combination antiretroviral therapy. Scand J Infect Dis 2006;38:74-75.

32 Duvic M, Crane MM, Conant M, Mahoney SE, Reveille JD, Lehrman SN: Zidovudine improves psoriasis in human immunodeficiency virus-positive males. Arch Dermatol 1994;130:447-451.

33 Berthelot P, Guglielminotti C, Frésard A, Lucht F, Perrot JL: Dramatic cutaneous psoriasis improvement in a patient with the human immunodeficiency virus treated with $2^{\prime}, 3^{\prime}$-dideoxy-3'-thyacytidine [correction of $2^{\prime}, 3^{\prime}$-dideoxycytidine] and ritonavir. Arch Dermatol 1997;133:531.

34 Bartke U, Venten I, Kreuter A, Gubbay S, Altmeyer P, Brockmeyer NH: Human immunodeficiency virus-associated psoriasis and psoriatic arthritis treated with infliximab. Br J Dermatol 2004;150:784-786. 